\title{
Should the appendix always be removed during surgery for mucinous ovarian tumors?
}

\author{
Bijal M. Patel ${ }^{1 *}$, Ava D. Desai ${ }^{1}$, Shilpa M. Patel ${ }^{1}$, Meeta H. Mankad ${ }^{1}$, \\ Pariseema S. Dave ${ }^{1}$, Chetana D. Parikh ${ }^{1}$, Amisha J. Gami ${ }^{2}$
}

\begin{abstract}
${ }^{1}$ Department of Gynecologic Oncology, ${ }^{2}$ Department of Pathology, Gujarat Cancer and Research Institute,
\end{abstract} Ahmedabad, Gujarat, India

Received: 13 December 2017

Accepted: 08 January 2018

\author{
*Correspondence: \\ Dr. Bijal M. Patel, \\ E-mail: bjl_ptl@rediffmail.com
}

Copyright: (c) the author(s), publisher and licensee Medip Academy. This is an open-access article distributed under the terms of the Creative Commons Attribution Non-Commercial License, which permits unrestricted non-commercial use, distribution, and reproduction in any medium, provided the original work is properly cited.

\begin{abstract}
Background: Appendectomy is performed in all mucinous ovarian tumors (MOT) identified intraoperatively to ensure microscopic metastases from appendix are not missed. Several recent studies suggested that appendectomy should only be performed in cases with a grossly abnormal appendix or with evidence of pseudomyxoma peritonei. Our study aimed to determine the frequency of malignancy in a grossly normal appendix in women undergoing surgery for borderline or malignant MOT.

Methods: In a single institution retrospective study, women undergoing surgery for MOT from January 1, 2008 to June 30, 2016 were included. Women with benign MOT, those with a history of either prior appendicectomy or prior gastrointestinal (GI) malignancy were excluded.

Results: Of 266 women identified with MOT, 153 with borderline and malignant MOT were included in the study after application of inclusion criteria. The study population comprised of 29 (18.95\%) borderline and $124(81.05 \%)$ malignant MOT. Among the borderline MOT, 13/29 had undergone appendectomy. Five (38.46\%) had grossly abnormal appendices of whom 1 had mucinous cystadenoma, 3 had borderline mucinous tumor and 1 had mucinous cystadenocarcinoma of the appendix. Histology was normal in all $8(61.54 \%)$ grossly normal appendices. Among the malignant MOT, 80/124 (64.52\%) underwent appendicectomy. Nineteen (23.46\%) had grossly abnormal appendices and histology was suggestive of adenocarcinoma of appendix. Histology was normal in all $62(76.54 \%)$ macroscopically normal appendices.
\end{abstract}

Conclusions: Present results suggest that appendectomy be performed only for those appendices that are grossly abnormal or associated with pseudomyxoma peritonei at surgery for MOT

Keywords: Appendix, Borderline tumors, Malignancy, Mucinous, Ovarian tumors, Pseudomyxoma peritonei

\section{INTRODUCTION}

Mucinous ovarian tumors (MOTs) comprise 3\% or less of all epithelial ovarian cancer in contrast to $12 \%$ quoted in earlier studies. ${ }^{1}$ Primary borderline and malignant MOT display overlapped morphological features including intestinal differentiation. Hence, they are often difficult to distinguish from metastatic appendiceal mucinous adenocarcinoma based on histological features and immunohistochemical (IHC) staining..$^{2-5}$ In addition, proper classification of mucinous tumors as primary or metastatic intraoperatively by frozen section (FS) is limited. ${ }^{3,6}$ To overcome these uncertainties on FS for MOT, appendectomy can be used to rule out the possibility of metastatic disease from an occult appendiceal primary mucinous carcinoma. Hence clinical 
practice guidelines in oncology outlined by the National Comprehensive Cancer Network (NCCN): Ovarian Cancer, Version 3, 2017, suggest that an appendectomy be performed in all MOT identified intraoperatively to ensure that occult or microscopic metastases from appendix are not missed. ${ }^{7,8}$ In cases with an unremarkable appendix, the mucinous neoplasm is classified as an ovarian primary. ${ }^{2.4 .5}$ However, in recent years, the role of routine appendicectomy in the management of MOT has become a subject of intense debate. ${ }^{1}$ Several recent studies suggested that appendicectomy should only be performed in cases with a grossly abnormal appendix or with evidence of pseudomyxoma peritonei (PMP). ${ }^{1,2,4,7-9}$ The incidence of finding disease in a grossly normal appendix is reported to be very rare in early stages of borderline and malignant MOTs. ${ }^{3,10}$ During the past few years, several studies have suggested immunological importance of appendix for the development and preservation of the intestinal immune system. ${ }^{11-14}$ It potentially serves to reinoculate the intestine with normal flora when unbeneficial pathogens arise in the gut. If the appendix is seen as a protective organ, an argument could be made for reducing or eliminating incidental appendectomies altogether. ${ }^{12}$ Taken a step further, this may be another reason for preservation of a grossly normal appendix at least in early stages of borderline and malignant MOT.

The aim of this study was to determine the frequency of abnormal pathology in grossly normal appendices in women undergoing surgery for borderline and malignant MOT. We present the data from our institute.

\section{METHODS}

In a single institution retrospective study, we evaluated all patients who underwent surgery for MOT from January 1, 2008 to June 30, 2016, at the Department of Gynecologic Oncology, Gujarat Cancer and Research Institute, Ahmedabad, India.

Inclusion criteria included borderline and malignant MOT. Exclusion criteria were women with benign MOT, a history of either prior appendicectomy or prior gastrointestinal (GI) malignancy.

Appendicectomy as part of staging MOT was performed by the gynaecologic oncologist. The practice of routine appendectomy of a normal-appearing appendix in staging laparotomy for MOT was dependent on the operating surgeon. Clinical and surgical data were collected from patient charts and the following variables the: age, operative notes (intraoperative findings, tumor laterality, gross appearance of appendix and ovaries and whether or not the appendix was removed), FS, type of surgery performed, histopathology report and IHC report. Primary ovarian cancers were staged according to International Federation of Gynecology and Obstetrics (FIGO) staging for ovarian tumors.
Primary appendicular carcinomas were staged according to American Joint Committee on Cancer Staging System (AJCC) for appendiceal carcinomas.

In the study design, appendiceal involvement was categorized as gross or microscopic. In primary adenocarcinoma, the appendix is usually enlarged, deformed, cystic and may be completely destroyed. An appendix of $>2 \mathrm{~cm}$ in diameter is often neoplastic. ${ }^{15}$ Involvement was to be considered microscopic when only histological sections were positive for malignancy the and the appendix was noted to be grossly normal by the operating surgeon and pathologist.

Histopathology was reported by a consultant pathologist specialized in gynecological oncology pathology. IHC was performed to confirm primary appendiceal carcinoma with ovarian metastases as required.

Statistical analysis was performed using SPSS software. The ability of gross appearance of an appendix to assess appendiceal pathology was assessed using chi-square test. A P value of $<.05$ was considered statistically significant. The study was approved by the Institutional Review Committee. (IRC)

\section{RESULTS}

Two hundred sixty-six patients who underwent surgery for MOT from January 1, 2008, to June 30, 2016, were evaluated. Among them 108 (40.60\%) were benign, 29 (10.90\%) borderline and 129 (48.49\%) malignant. Among the borderline and malignant subgroup, 5 patients had a past history of appendicectomy. After application of inclusion criteria, 153 women were included in the study. Of the $153,29(18.95 \%)$ were borderline and 124 $(81.05 \%)$ were malignant. In the borderline subgroup, the median age was 44.5 years (range, 15-70 years); and 47 years (range, 13-80 years) in the malignant subgroup.

\section{Borderline cases}

Of the 29 patients, $16(55.17 \%)$ with grossly normal appendices did not undergo appendicectomy. Appendicectomy was performed in $13(44.83 \%)$ patients. Eight $(61.54 \%)$ had a grossly normal appendix and histology was normal in all the 8 cases. The appendix was grossly abnormal in $5(38.46 \%)$ patients (Figure 1$)$.

Characteristics of these 5 patients are given in Table 1. One patient had mucinous cystadenoma, 3 had borderline mucinous tumor and 1 had mucinous cystadenocarcinoma of the appendix. Of 3 patients with borderline mucinous tumor of ovary and appendix, 2 had IHC suggestive of primary appendicular tumor. In the remaining case, omentum showed changes consistent with PMP. Hence this was also considered to be a primary appendicular cancer. 
Table 1: Characteristic of patients with grossly abnormal appendices in borderline MOT.

\begin{tabular}{|c|c|c|c|c|c|c|}
\hline Age & Laterality & Surgery & $\begin{array}{l}\text { Gross appearance of } \\
\text { appendix }\end{array}$ & $\begin{array}{l}\text { Histology of } \\
\text { Appendix }\end{array}$ & $\begin{array}{l}\text { Histology of } \\
\text { Ovary }\end{array}$ & $\begin{array}{l}\text { Stage } \\
\text { (appendicular } \\
\text { cancer) }\end{array}$ \\
\hline 45 & Bilateral & $\begin{array}{l}\mathrm{TAH}+\mathrm{BSO}+ \\
\text { appendicectomy }\end{array}$ & $\begin{array}{l}\text { Cystically dilated } \\
\text { with mucin deposits }\end{array}$ & $\begin{array}{l}\text { Borderline } \\
\text { mucinous } \\
\text { tumor }\end{array}$ & $\begin{array}{l}\text { Borderline } \\
\text { mucinous tumor } \\
+ \text { PMP }\end{array}$ & IVA \\
\hline 48 & Unilateral & $\begin{array}{l}\text { TAH+BSO+ } \\
\text { appendicectomy }\end{array}$ & $\begin{array}{l}\text { Distended and } \\
\text { swollen }\end{array}$ & $\begin{array}{l}\text { Mucinous } \\
\text { cystadenoma }\end{array}$ & $\begin{array}{l}\text { Borderline } \\
\text { mucinous tumor }\end{array}$ & - \\
\hline 50 & Unilateral & $\begin{array}{l}\mathrm{TAH}+\mathrm{BSO}+ \\
\text { appendicectomy }\end{array}$ & Distended & $\begin{array}{l}\text { Borderline } \\
\text { mucinous } \\
\text { tumor }\end{array}$ & $\begin{array}{l}\text { Borderline } \\
\text { mucinous tumor }\end{array}$ & IVA \\
\hline 75 & Bilateral & $\begin{array}{l}\mathrm{TAH}+\mathrm{BSO}+ \\
\text { appendicectomy }\end{array}$ & $\begin{array}{l}\text { Abundant mucin in } \\
\text { the wall and meso } \\
\text { appendix }\end{array}$ & $\begin{array}{l}\text { Mucinous } \\
\text { cystadeno } \\
\text { carcinoma }\end{array}$ & $\begin{array}{l}\text { Right- mucinous } \\
\text { cystadenoma } \\
\text { Left- borderline } \\
\text { mucinous tumor }\end{array}$ & IVA \\
\hline 54 & Unilateral & $\begin{array}{l}\text { TAH+BSO+ } \\
\text { appendicectomy }\end{array}$ & Nodular & $\begin{array}{l}\text { Borderline } \\
\text { mucinous } \\
\text { tumor }\end{array}$ & $\begin{array}{l}\text { Borderline } \\
\text { mucinous tumor }\end{array}$ & IVA \\
\hline
\end{tabular}

All cases had peritoneal washings, infracolic omentectomy as well; BSO-Bilateral Salpingo-Oophorectomy; PMP-Pseudomyxoma Peritonei; TAH-Total Abdominal Hysterectomy.

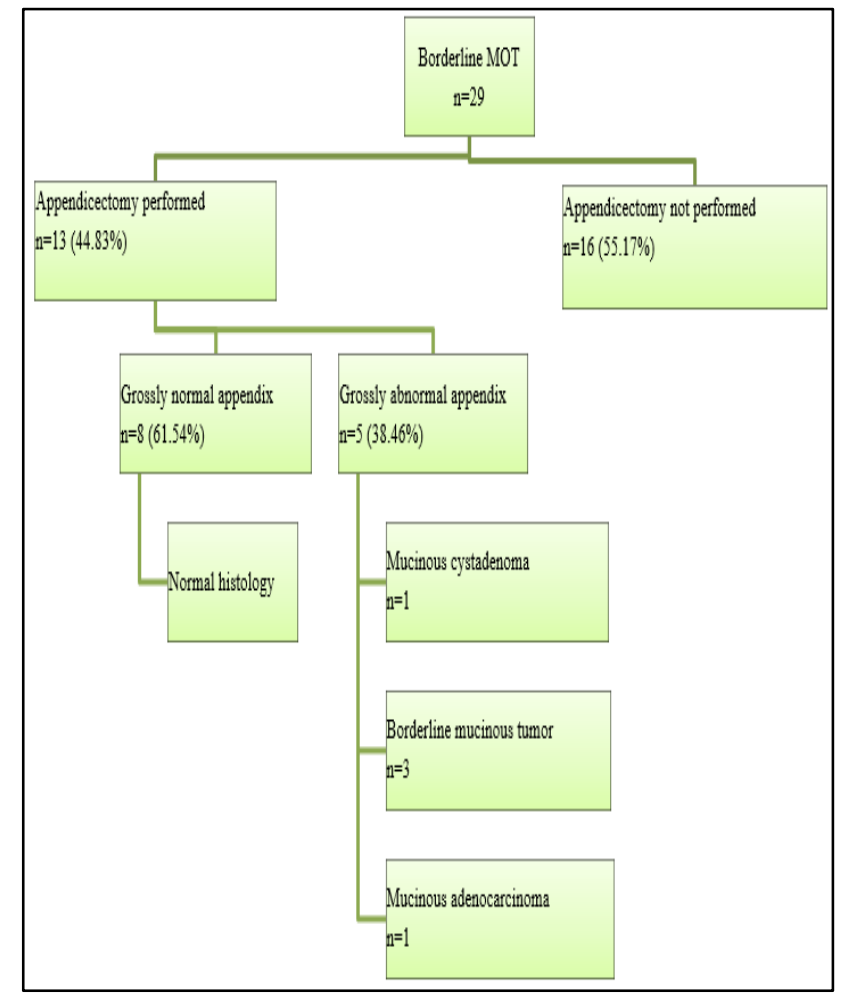

Figure 1: Gross and microscopic appearance of appendix in borderline MOT.

\section{Malignant cases}

Of the 124 patients included in the study, 43 (34.68\%) did not undergo an appendicectomy, as the appendix seemed to be grossly normal intraoperatively. Appendicectomy was planned in $81(65.32 \%)$ patients but was not feasible in 1 patient with an unresectable ileocecal mass. Of the 80 appendicectomies performed, $62(76.54 \%)$ had a grossly normal appendix. None of these showed any appendicular disease on histopathology.

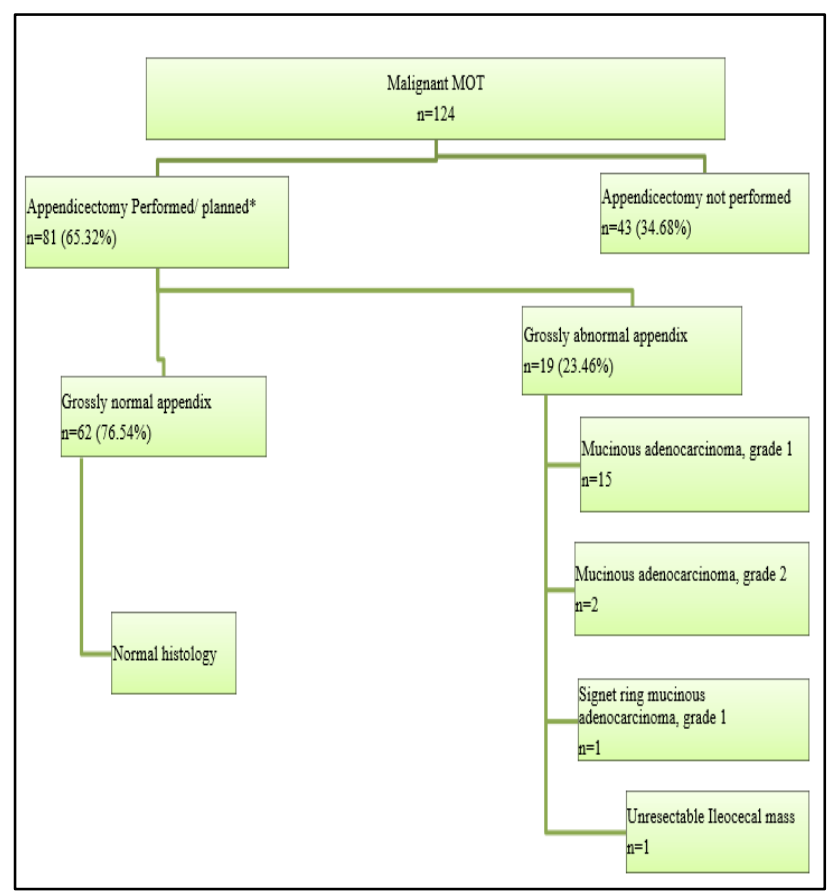

*One patient had an unresectable ileocecal mass involving appendix. Histology of the omentum revealed malignant metastatic mucinous adenocarcinoma.

Figure 2: Gross and microscopic appearance of appendix in malignant MOT.

The appendix was grossly abnormal in $19(23.46 \%)$ patients (Figure 2). 
Characteristics of these 19 patients are given in Table 2 . In 16 of the 19 patients, complete surgery could be performed. Histopathology of the 16 ovarian tumors with the grossly abnormal appendices showed well differentiated mucinous adenocarcinoma in 13 cases, moderately differentiated mucinous adenocarcinoma in 2 cases and signet ring mucinous adenocarcinoma in 1 case. In all 16 cases, similar histology was seen in both ovaries and appendices.

Table 2: Characteristic of patients with grossly abnormal appendices in malignant MOT.

\begin{tabular}{|c|c|c|c|c|c|c|}
\hline Age & Laterality & Surgery & $\begin{array}{l}\text { Gross appearance } \\
\text { of appendix }\end{array}$ & $\begin{array}{l}\text { Histology of } \\
\text { appendix }\end{array}$ & Histology of ovary & $\begin{array}{l}\text { Stage } \\
\text { (appendicular } \\
\text { cancer) }\end{array}$ \\
\hline 75 & Unilateral & $\begin{array}{l}\text { TAH+BSO } \\
\text { +right hemicolectomy }\end{array}$ & $\begin{array}{l}\text { Nodular firm with } \\
\text { mucinous surface }\end{array}$ & $\begin{array}{l}\text { Mucinous adeno } \\
\text { carcinoma }\end{array}$ & $\begin{array}{l}\text { Metastatic mucinous } \\
\text { adeno carcinoma }\end{array}$ & IVA \\
\hline 40 & Bilateral & $\begin{array}{l}\mathrm{BSO}+ \\
\text { appendicectomy }\end{array}$ & $\begin{array}{l}\text { Nodular hard } \\
\text { surface }\end{array}$ & $\begin{array}{l}\text { Mucinous adeno } \\
\text { carcinoma }\end{array}$ & $\begin{array}{l}\text { Metastatic mucinous } \\
\text { adeno carcinoma }\end{array}$ & IVA \\
\hline 42 & Bilateral & $\begin{array}{l}\text { TAH+BSO+BPLND } \\
\text { +appendicectomy }\end{array}$ & $\begin{array}{l}\text { Thickened and } \\
\text { firm wall }\end{array}$ & $\begin{array}{l}\text { Mucinous adeno } \\
\text { carcinoma }\end{array}$ & $\begin{array}{l}\text { Metastatic mucinous } \\
\text { adeno carcinoma }\end{array}$ & IVA \\
\hline 47 & - & $\begin{array}{l}\text { Aspiration of mucinou: } \\
\text { material from abdomin } \\
\text { cavity+right } \\
\text { hemicolectomy }\end{array}$ & $\begin{array}{l}\text { Distended with } \\
\text { mucin deposits on } \\
\text { external surface }\end{array}$ & $\begin{array}{l}\text { Mucinous adeno } \\
\text { carcinoma }\end{array}$ & $\begin{array}{l}\text { Unresectable } \\
\text { Ovarian mass }\end{array}$ & IVA \\
\hline 40 & Bilateral & $\begin{array}{l}\text { TAH+BSO } \\
\text { +right hemicolectomy }\end{array}$ & $\begin{array}{l}\text { Replaced by } \\
\text { nodular growth }\end{array}$ & $\begin{array}{l}\text { Mucinous adeno } \\
\text { carcinoma }\end{array}$ & $\begin{array}{l}\text { Metastatic mucinous } \\
\text { adeno carcinoma }\end{array}$ & IVA \\
\hline 45 & Bilateral & $\begin{array}{l}\text { TAH+BSO+ } \\
\text { appendicectomy }\end{array}$ & Nodular growth & $\begin{array}{l}\text { Mucinous adeno } \\
\text { carcinoma }\end{array}$ & $\begin{array}{l}\text { Metastatic mucinous } \\
\text { adeno carcinoma }\end{array}$ & IVA \\
\hline 35 & - & $\begin{array}{l}\text { Debulking of } \\
\text { mucinous material + } \\
\text { peritonectomy }\end{array}$ & $\begin{array}{l}\text { Mass involving } \\
\text { appendix }\end{array}$ & $\begin{array}{l}\text { Ileocecal mass } \\
\text { not resectable }\end{array}$ & $\begin{array}{l}\text { Unresectable } \\
\text { Ovarian mass }\end{array}$ & IVA \\
\hline 79 & Bilateral & $\begin{array}{l}\text { TAH+BSO+ } \\
\text { appendicectomy }\end{array}$ & $\begin{array}{l}\text { Hard nodules and } \\
\text { thickened wall }\end{array}$ & $\begin{array}{l}\text { Adenocarcinoma } \\
\text { signet ring cell } \\
\text { type }\end{array}$ & $\begin{array}{l}\text { Metastatic } \\
\text { adenocarcinoma } \\
\text { signet ring cell type }\end{array}$ & IVA \\
\hline 58 & Bilateral & $\begin{array}{l}\mathrm{BSO}+ \\
\text { appendicectomy }\end{array}$ & $\begin{array}{l}\text { Nodular hard } \\
\text { surface }\end{array}$ & $\begin{array}{l}\text { Mucinous adeno } \\
\text { carcinoma }\end{array}$ & $\begin{array}{l}\text { Metastatic mucinous } \\
\text { adeno carcinoma }\end{array}$ & IVA \\
\hline 50 & Unilateral & $\begin{array}{l}\text { TAH+BSO+ } \\
\text { BPLND+ } \\
\text { appendicectomy }\end{array}$ & $\begin{array}{l}\text { Nodular with } \\
\text { mucin on external } \\
\text { surface }\end{array}$ & $\begin{array}{l}\text { Mucinous adeno } \\
\text { carcinoma+PMP }\end{array}$ & $\begin{array}{l}\text { Metastatic mucinous } \\
\text { adeno carcinoma }\end{array}$ & IVA \\
\hline 65 & Bilateral & $\begin{array}{l}\text { BSO+ } \\
\text { appendicectomy+ } \\
\text { removal of tumor } \\
\text { over small bowel }\end{array}$ & $\begin{array}{l}\text { Thickened wall } \\
\text { with mucin } \\
\text { externally }\end{array}$ & $\begin{array}{l}\text { Mucinous } \\
\text { adenocarcinoma }\end{array}$ & $\begin{array}{l}\text { Metastatic mucinous } \\
\text { adenocarcinoma+ PMF }\end{array}$ & IVA \\
\hline 55 & Unilateral & $\begin{array}{l}\text { TAH+BSO+ } \\
\text { Peritonectomy+appe } \\
\text { ndicectomy }\end{array}$ & Nodular & $\begin{array}{l}\text { Mucinous adeno } \\
\text { carcinoma }\end{array}$ & $\begin{array}{l}\text { Metastatic mucinous } \\
\text { adeno carcinoma }\end{array}$ & IVA \\
\hline 35 & Bilateral & $\begin{array}{l}\text { TAH+BSO } \\
\text { +right hemicoloctomy }\end{array}$ & $\begin{array}{l}\text { Distended and } \\
\text { cystically dilated }\end{array}$ & $\begin{array}{l}\text { Mucinous } \\
\text { adenocarcinoma }\end{array}$ & $\begin{array}{l}\text { Metastatic mucinous } \\
\text { adeno carcinoma }\end{array}$ & IVA \\
\hline 50 & Bilateral & $\begin{array}{l}\text { BSO+right } \\
\text { hemicolectomy }\end{array}$ & $\begin{array}{l}\text { Nodular mucinous } \\
\text { growth }\end{array}$ & $\begin{array}{l}\text { Mucinous adeno } \\
\text { carcinoma }\end{array}$ & $\begin{array}{l}\text { Metastatic mucinous } \\
\text { adeno carcinoma }\end{array}$ & IVA \\
\hline 50 & Bilateral & $\begin{array}{l}\text { BSO+ } \\
\text { appendicectomy }\end{array}$ & $\begin{array}{l}\text { Mucinous surface } \\
\text { with thickened wall }\end{array}$ & $\begin{array}{l}\text { Mucinous } \\
\text { adenocarcinoma }\end{array}$ & $\begin{array}{l}\text { Metastatic mucinous } \\
\text { adeno carcinoma }\end{array}$ & IV B \\
\hline 70 & Unilateral & $\begin{array}{l}\text { USO+ } \\
\text { appendicectomy }\end{array}$ & $\begin{array}{l}\text { Distended with } \\
\text { mucin deposits }\end{array}$ & $\begin{array}{l}\text { Mucinous } \\
\text { adenocarcinoma }\end{array}$ & $\begin{array}{l}\text { Metastatic mucinous } \\
\text { adeno carcinoma }\end{array}$ & IVB \\
\hline 46 & Bilateral & $\begin{array}{l}\mathrm{BSO}+ \\
\text { appendicectomy }\end{array}$ & Nodular and hard & $\begin{array}{l}\text { Mucinous } \\
\text { adenocarcinoma }\end{array}$ & $\begin{array}{l}\text { Metastatic mucinous } \\
\text { adeno carcinoma }\end{array}$ & IVA \\
\hline 62 & - & $\begin{array}{l}\text { Right } \\
\text { hemicoloctomy }\end{array}$ & $\begin{array}{l}\text { Friable ileocecal } \\
\text { mass }\end{array}$ & $\begin{array}{l}\text { Mucinous } \\
\text { Adeno carcinoma }\end{array}$ & $\begin{array}{l}\text { Unresectable } \\
\text { Ovarian mass }\end{array}$ & IVA \\
\hline 60 & Bilateral & $\begin{array}{l}\mathrm{TAH}+\mathrm{BSO}+ \\
\text { appendicectomy }\end{array}$ & Appendicular mass & $\begin{array}{l}\text { Mucinous adeno } \\
\text { carcinoma }\end{array}$ & $\begin{array}{l}\text { Metastatic mucinous } \\
\text { adeno carcinoma }\end{array}$ & IVA \\
\hline
\end{tabular}

All cases had peritoneal washings, infracolic ometectomy as well; BSO: Bilateral Salpingo-Oophorectomy; USO: Unilateral SalpingoOophorectomy; TAH: Total Abdominal Hysterectomy; BPLND” Bilateral Pelvic Lymph Node Dissection; PMP: Pseudomyxoma Peritonei 
In 3 patients' complete surgery was not feasible. In 1 case both ovarian mass and ileocecal mass were not resectable. In this, the histology of omentum was malignant metastatic mucinous adenocarcinoma. In the remaining 2 cases, the ovarian tumors were not resectable and the histology of appendix was well differentiated mucinous adenocarcinoma in both cases.

Table 3: Immunohistochemical (IHC) profile of grossly abnormal appendices of borderline/malignant MOT.

\begin{tabular}{|llllll|}
\hline Malignant/borderline & CK20 & CEA & CK7 & CA125 & CDX2 \\
\hline Malignant & positive & positive & focal positive & - & - \\
\hline Malignant & positive & positive & focal positive & negative & - \\
\hline Malignant & positive & positive & positive & - & positive \\
\hline Malignant & positive & - & negative & - & - \\
\hline Malignant & positive & positive & negative & negative & - \\
\hline Malignant & positive & positive & negative & - & - \\
\hline Malignant & positive & positive & negative & - & positive \\
\hline Malignant & positive & positive & focal positive & - & - \\
\hline Malignant & positive & positive & negative & - & - \\
\hline Malignant & positive & positive & focal positive & - & - \\
\hline Malignant & positive & positive & negative & negative & - \\
\hline Malignant & positive & positive & focal positive & - & - \\
\hline Malignant & positive & positive & negative & - & - \\
\hline Borderline & positive & positive & negative & - & - \\
\hline Borderline & positive & positive & negative & - & - \\
\hline
\end{tabular}

Table 4: Prediction of coexisting appendiceal pathology based on gross findings and histology of appendix.

\begin{tabular}{|llll|}
\hline Type of MOT & $\begin{array}{l}\text { Appendix } \\
\text { (Gross+Histology) }\end{array}$ & P value \\
\hline & $\begin{array}{lll}\text { Abnormal } \\
\text { Normal }\end{array}$ & \\
\hline Borderline MOT & 5 & 8 & $<.05$ \\
\hline Malignant MOT & 19 & 62 & $<.05$ \\
\hline
\end{tabular}

IHC was performed in 13 malignant and 2 borderline MOT cases. IHC profile of grossly abnormal appendices of borderline and malignant MOT is given in Table 3. All 15 cases showed CK20 and CEA positive staining. 9 cases displayed the CK20+/CK7 negative immunoprofile confirming an appendicular primary. One case with CK20/CK7 positive staining had CDX2 positive staining supporting a GI primary. 5 cases showed only focal CK7 positivity with strong CK20 staining indicating that the ovarian tumors were metastatic from appendix.

To determine if intraoperative gross appearance of appendix could predict appendiceal pathology, a chisquare test was performed (Table 4). The appendix was grossly abnormal in 19/81 cases of malignant MOT and $5 / 13$ in borderline MOT. The ability of the gross appearance of the appendix to predict appendiceal pathology was statistically significant i.e. p-value was $<0.05$ in both borderline and malignant MOT.

In all 19 cases with grossly abnormal appendices, the ovarian tumor was bilateral in 12 cases. Metastatic spread was also seen on the serosal surface on the large or small bowel (16 cases), omentum (17 cases), liver surface (3 cases), undersurface of diaphragm (3 cases), abdominal wall peritoneum ( 3 cases), uterus ( 1 case) and bladder ( 1 case). In 1 case, there was an extensive mucin pool with tumor cells suggestive of PMP.

\section{DISCUSSION}

In this study, we examined the relationship between gross appearance and histology of the appendix in operated cases of MOT. Appendicectomy in MOT has been the practice at our institution as in many other centers. This study aimed to question the longstanding protocol of removing even a normal-appearing appendix based on evidence that some MOTs are secondary to an occult appendiceal primary lesion.

The differential diagnosis of primary or metastatic MOT is difficult. The differential diagnosis for all MOTs particularly those that have spread beyond the ovaries includes primaries from the GI tract- mainly large intestine, appendix and pancreas and less commonly stomach and biliary tract. Endocervical mucinous tumor can metastasize to the ovary in rare instances. Correct diagnosis is important not only for prognosis but also for further treatment planning. ${ }^{16}$

Primary MOTs are typically large, unilateral, multi-cystic tumors with smooth capsules and most often unassociated with an extraovarian disease. Primary mucinous ovarian carcinoma usually is associated with areas showing borderline malignancy. Mucinous carcinoma also 
displays confluent glandular or expansile pattern and is rarely destructive with stromal invasion. ${ }^{3,8}$

In contrast, typical features of metastatic MOT include bilateral ovarian involvement, a smaller size of ovarian masses $(<13 \mathrm{~cm})$ and ovarian surface involvement. Histologically numerous pools of mucin dissecting the ovarian stroma (i.e. pseudomyxoma ovarii), a nodular pattern of invasion, an extensive infiltrative pattern of stromal invasion and lymphovascular invasion are seen. IHC profile shows CK20+, CEA+, CDX2+, CK7-, MUC2+, MAC5AC. ${ }^{1,3,8,16}$ However, some metastatic appendiceal carcinomas may manifest one or more gross and microscopic features suggesting a primary ovarian tumor. ${ }^{17}$ For all these reasons, the NCCN guidelines: Ovarian Cancer, Version 3, 2017 continue to recommend appendectomy at primary surgery in patients with suspected or confirmed MOT to rule out the possibility of a primary appendiceal cancer. ${ }^{8}$

A primary adenocarcinoma of appendix is rare, representing about $0.4 \%$ of all GI malignant tumors. ${ }^{1}$ Preoperative diagnosis is difficult, and it is often discovered incidentally intraoperatively. When these tumors metastasize to the ovary, they are often misdiagnosed as an adnexal mass preoperatively. However, the appendix is almost always grossly abnormal intraoperatively in such cases. , $^{1,8,17}$

In the present study, appendicectomy was planned in 81 $(65.32 \%)$ patients but was not feasible in 1 patient with an unresectable ileocecal mass. Among them, 19 $(23.46 \%)$ were found to have a primary appendiceal tumor and with metastases to ovary and not vice versa. In all these 19 cases, the appendix was grossly abnormal. In the remaining $62(76.54 \%)$ cases, the appendix was grossly normal. None of these were found to have appendicular involvement on histology. Other studies also show similar findings. ${ }^{1,2,4,7-10}$ Only grossly abnormal appendices were associated with pathological findings. However, in a retrospective review of 71 patients with MOT, who underwent appendicectomy Cheng et al found metastasis from an ovary to the appendix in both cases of borderline MOT and the 1 out 5 cases of malignant MOT with grossly abnormal appendix. ${ }^{10}$

Similarly, in borderline MOT, of the 13 patients in whom appendicectomy the, $5(38.46 \%)$ had grossly abnormal appendices. Among these 5 patients, histological examination revealed mucinous cystadenoma in 1 , mucinous adenocarcinoma in 1 and borderline mucinous tumor in 3 patients. In the remaining $8(61.54 \%)$ patients, the appendix was grossly normal. None of these were found to have appendicular involvement on histology. Hence it is proposed that if the appendix is grossly normal and there is no evidence of PMP, appendicectomy may be avoided. A study by Mukhopadhyay et al recommended removal of the only grossly abnormal appendix in borderline and malignant MOT. In their study, incidence of the pathologic appendix was $2.5 \%$ in borderline and $24 \%$ in malignant MOT. All patients had grossly abnormal appendix. ${ }^{1}$ Recently Cheng et al performed a meta-analysis of the literature (914 borderline and malignant MOT with appendicectomies) to further validate their findings. The estimated malignant pathology rate in macroscopically normal versus abnormal appendices was $1.4 \%$ and $59 \%$ respectively. They concluded that a careful intraoperative exploration of the appendix is crucial, but appendicectomy is only warranted when the appendix is abnormal. ${ }^{10}$ The result of this study is in agreement with this study as in the absence of PMP none of the normal appearing appendices showed primary or metastatic disease.

Interestingly, present results are not dissimilar from a retrospective study by Ozcan and colleagues. They included 129 patients with 120 of MOT and 9 of primary mucinous appendix carcinoma. In all 9 patients of primary appendiceal carcinoma, the appendix seemed abnormal at surgery. Of these, 4 had ovarian metastases and PMP. Pathologic diagnosis was normal in all 65 patients who underwent appendectomy and whose appendix was grossly normal. No recurrence was detected during a median follow-up period of 7 years. Hence it appears unnecessary to perform an appendectomy in patients operated for an adnexal mass and whose FS was reported as MOT if the appendix is grossly normal intraoperatively and there is no evidence of PMP. . $^{-}$

Similarly, in a study by Lin et al, no mucinous tumors of the appendix were identified in a grossly normal appendix. There was no association between wound complication and appendicectomy. ${ }^{7}$ Feigenberg et al concluded that appendicectomy in the absence of a grossly abnormal appendix, evidence of metastatic disease or PMP at least in apparent stage I borderline and malignant MOT. ${ }^{8}$ The retrospective study by Kleppe et al recommended thorough inspection of the appendix in patients with an MOT with borderline features. An appendectomy should only be performed when the appendix is grossly abnormal. ${ }^{9}$

The study by Ramirez et al concluded that even though appendicectomy is not associated with complications, it should not be removed at the time of surgery for apparent early-stage ovarian cancer. ${ }^{18}$ Fontanelli and colleagues recommended appendicectomy as a part of cytoreductive surgery in advanced disease but not at staging surgery with a normal appearing appendix for ovarian carcinoma, irrespective of subtype. ${ }^{19}$

One belief is that prior appendicectomy may offer protection against development of MOT. In a study by Elias et al, 287 cases of MOT were compared against 2339 age-matched controls from the New England casecontrol study. They concluded that prior appendectomy did not reduce the risk of MOT (OR 1.28, 95\% CI 0.831.92, $\mathrm{p}=0.23)$. They evaluated the frequency of microscopic, isolated appendiceal metastases from the 
ovary. No microscopic metastasis was found in grossly normal appendix. Removal of appendix is mandatory if grossly abnormal or when widespread metastatic disease makes the organ of origin uncertain or in the presence of PMP as this is almost always of appendiceal origin. A thorough evaluation of the appendix intraoperatively is recommended. ${ }^{2}$

In cases where the appendix at the time of surgery for suspected MOT, IHC staining may help distinguish ovarian from appendiceal or colorectal carcinomas. Malignant MOT tends to be CK7+/CK20-/MUC2-/CDX2-, with variable expression of PAX8. In contrast, mucinous colorectal cancers and mucinous appendiceal cancers usually feature a CK7-/CK20+/ MUC2+/CDX2+/PAX8immunophenotype. $^{2}$ In the present study, IHC was performed in a total of 13 malignant MOT and 2 borderline MOT cases with grossly abnormal appendices. All the 15 showed CK20 and CEA positive staining and 9 displayed a CK20+/CK7 negative immunoprofile confirming an appendicular primary.

Present findings differ from those in the study by Moore and colleagues who recommended routine appendicectomy in the management of all MOT. They studied 123 cases of which 119 were MOT and 4 were metastatic tumors to the ovaries. They reported a $24 \%$ prevalence of appendiceal pathology regardless of the gross appearance of the appendix. They showed 6\% of occult microscopic appendiceal pathology even in a grossly normal appendix. ${ }^{5}$ Similarly, Rosendahl et al prospectively gathered data on 269 patients with confirmed malignant MOT. In their study, in 3 cases, appendix was macroscopically normal, and metastases were discovered only during microscopic evaluation. They cited many reasons for appendicectomy namely complete staging, differential diagnosis of primary versus metastatic MOT, ease of performance, no increase in morbidity and the fact that a grossly normal appendix does not exclude microscopic disease. Also, risk of future appendicitis necessitating surgery is avoided. ${ }^{20}$

The potential risks of performing an appendectomy for a grossly normal appendix include hemorrhage, peritonitis, intraabdominal abscess, bowel perforation, intestinal obstruction, cost, and increased time in the operating room. However, many studies including ours have shown no increase in complications from appendectomies at the time of benign and malignant gynecological surgeries. ${ }^{7,18-}$ 21 One can argue that, although the incidence of identifying a primary mucinous appendix tumor is very low, performing an appendectomy has no major negative consequences. ${ }^{9}$

The function of the appendix is still the subject of debate. In recent years, several studies have suggested that the appendix plays an important role in the development and preservation of intestinal immune system. The appendix harbors normal flora and can aid in repopulation of commensal bacteria and lessen the uncontrollable overgrowth of abnormal, including antibiotic-resistant bacteria in the intestine. ${ }^{11-14}$ In this sense, appendicectomy may be correlated with antibiotic resistance in patients with severe bacterial infections. Kawanishi concluded that prior appendicectomy was an independent risk factor for the antibiotic-resistant bacteria in biliary tract infections. ${ }^{11}$ Moreover, Clanton et al reported that the rate of appendectomy in the patients whose Clostridium difficile infection [CDI] led to colectomy, was significantly higher than the calculated lifetime risk, suggesting an association of appendectomy and severe CDI resulting in colectomy. ${ }^{12}$ Considering these facts, the appendix should no longer be considered as a rudimentary organ and one must carefully decide whether appendectomy is indicated for appendicitis.

This is a large study conducted over a span of 9 years and 6 months in a tertiary care regional cancer institute with a large referral base and well established Gynecologic Oncology and Oncopathology Departments. The main limitation is the retrospective nature of clinical data. As many patients did not have appendicectomy, there may be an underestimation of incidental pathology in grossly normal appendices.

\section{CONCLUSION}

In conclusion, on the basis of the results of the present study and data previously reported in the literature, when a grossly normal appendix is removed during surgery for MOT, no primary or metastatic appendiceal tumor of mucinous histology is found. All primary mucinous appendiceal tumors were associated with the grossly abnormal appearing appendices. Careful intraoperative inspection of the appendix is mandatory.

We recommend that appendectomy be performed only for those appendices that are grossly abnormal or associated with pseudomyxoma peritonei (PMP) at the time of surgery for mucinous ovarian tumor (MOT) due to the high prevalence of primary appendiceal cancer mimicking an ovarian tumor in such cases. Unnecessary appendectomies may thus be prevented keeping in mind the proposed important immunological role of the appendix. However, further prospective studies with a larger sample size should be carried out before current recommendations can be changed.

Funding: No funding sources

Conflict of interest: None declared

Ethical approval: The study was approved by the Institutional Ethics Committee

\section{REFERENCES}

1. Mukhopadhyay D, Rajab R, Nobbenhuis M, Dilley J, Heath O, Wang J, et al. Outcome of Appendicectomies at surgery for mucinous ovarian 
neoplasms: report from a UK Center and review of literature, Int J Gynecol Cancer. 2016;26(6):1020-6.

2. Kevin M, Intidhar S, Allison F, Jason L, Leona A, Hirsch MS, et al. Prior appendectomy does not protect against subsequent development of malignant or borderline mucinous ovarian neoplasms. Gynecol Oncol. 2014;132:328-33.

3. Brown J, Frumovitz M. Mucinous tumors of the ovary: current thoughts on diagnosis and management. Curr Oncol Rep. 2014;16(6):389.

4. Ozcan A, T€oz E, Turan V, Sahin C, Kopuz A, Ata $\mathrm{C}$, et al. Should we remove the normal-looking appendix during operations for borderline mucinous ovarian neoplasms?: a retrospective study of 129 cases. Int J Surg. 2015;18:99-103.

5. Moore L, Gajjar K, Jimenez-Linan M, Crawford R. Prevalence of appendiceal lesions in appendicectomies performed during surgery for mucinous ovarian tumors: a retrospective study. Int J Gynecol Cancer. 2016;26:1386-9.

6. Storms AA, Sukumvanich P, Monaco SE, Beriwal S, Krivak TC, Olawaiye AB, et al. Mucinous tumors of the ovary: diagnostic challenges at frozen section and clinical implications. Gynecol Oncol. 2012;125:75-9.

7. Lin JE, Seo S, Kushner DM, Rose SL. The role of appendectomy for mucinous ovarian neoplasms. Am J Obstet Gynecol. 2013;208:46e1-4.

8. Feigenberg T, Covens A, Ghorab Z, Ismiil N, Dube' $\mathrm{V}$, Saad RS, et al. Is routine appendectomy at the time of primary surgery for mucinous ovarian neoplasms beneficial? Int $\mathrm{J}$ Gynecol Cancer. 2013;23:1205-9.

9. Kleppe M, Bruls J, Gorp VT, Massuger L, Slangen BFM, Van de Vijver KK, et al. Mucinous borderline tumours of the ovary and the appendix: a retrospective study and overview of the literature. Gynecol Oncol. 2014;133:155-8.

10. Cheng A, Li M, Kanis MJ, Ying Xu, Zhang Q, Cui B et al. Is it necessary to perform routine appendectomy for mucinous ovarian neoplasms? A retrospective study and meta-analysis. Gynecol Oncol. 2017;144(1):215-22.

11. Kawanishi K, Kinoshita J, Abe H, Kakimoto $\mathrm{T}$, Yasuda Y, Hara T, et al. Appendectomy as a risk factor for bacteremic biliary tract infection caused by antibiotic-resistant pathogens. BioMed Res Int. 2017:3276120.
12. Clanton J, Subichin M, Drolshagen K, Daley T, Firstenberg MS. Fulminant clostridium difficile infection: an association with prior appendectomy? World J Gastrointestinal Surg. 2013;5:233-8.

13. Guinane CM, Tadrous A, Fouhy F, Ryan C, Dempsey E, Murphy B, et al. Microbial composition of human appendices from patients following appendectomy. Bio. 2013;4(1):e00366-12.

14. Kooij A, Sahami S, Meijer SL, Buskens CJ, Te Velde AA. The immunology of the vermiform appendix: a review of the literature. Clinical Experimental Immunol. 2016;186:1-9.

15. Ramaswamy V. Pathology of mucinous appendiceal tumors and pseudomyxoma peritonei. Indian J Surg Oncol. 2016;7(2):258-67.

16. Ledermann J, Raja F. Mucinous cancers: ovary. In: Rare and Uncommon Gynecological Cancers. In: Reed N, Green JA, Gershenson DM, Siddiqui N, Connor R, eds. Rare and uncommon gynecological cancers. Berling Heidelberg: Springer; 2011:67-73.

17. Dietrich CS, Desimone CP, Modesitt SC, DePriest PD, Ueland FR, Pavlik EJ, et al. Primary appendiceal cancer: gynecologic manifestations and treatment options. Gynecol Oncol. 2007;104:602-6.

18. Ramirez PT, Slomovitz BM, McQuinn L, Levenback C, Coleman RL. Role of appendectomy at the time of primary surgery in patients with early-stage ovarian cancer. Gynecol Oncol. 2006;103:888-90.

19. Fontanelli R, Paladini D, Raspagliesi F, E. DI RE. The role of appendectomy in surgical procedures for ovarian cancer. Gynecol Oncol. 1992;46:42-4.

20. Rosendahl M, Oester LAH, Høgdall CK. The importance of appendectomy in surgery for mucinous adenocarcinoma of the ovary. Int $\mathbf{J}$ Gynecol Cancer. 2017;27:430-6.

21. Salom EM, Schey D, Penalver M, Gomez-Marın O, Lambrou N, Almeida Z, et al. The safety of incidental appendectomy at the time of abdominal hysterectomy. Am J Obstet Gynecol. 2003;189:15638 .

Cite this article as: Patel BM, Desai AD, Patel SM, Mankad MH, Dave PS, Parikh CD, et al. Should the appendix always be removed during surgery for mucinous ovarian tumors? Int J Reprod Contracept Obstet Gynecol 2018;7:677-84. 